\title{
Sarcopenia: Molecular Pathways and Potential Targets for Intervention
}

\author{
Jorge Pascual-Fernández ${ }^{1}$, Alejandro Fernández-Montero ${ }^{2}{ }^{(0)}$, Alfredo Córdova-Martínez ${ }^{3}{ }^{(D)}$, \\ Diego Pastor ${ }^{4} \mathbb{D}$, Alejandro Martínez-Rodríguez ${ }^{5,6} \mathbb{D}$ and Enrique Roche ${ }^{6,7,8, *(\mathbb{D})}$ \\ 1 Medical Extrahospital Emergency Service of Navarra, 31500 Pamplona, Spain; jpfoliva@gmail.com \\ 2 Prevention and Health Service, University Clinic of Navarra, 31008 Pamplona, Spain; afmontero@unav.es \\ 3 Biochemistry, Molecular Biology and Physiology, Faculty of Health Sciences, GIR Physical Exercise and \\ Aging, University of Valladolid, Campus Duques de Soria, 42004 Soria, Spain; a.cordova@uva.es \\ 4 Department of Sport Sciences, University Miguel Hernández (Elche), 03202 Alicante, Spain; dpastor@umh.es \\ 5 Department of Analytical Chemistry, Nutrition and Food Sciences, Faculty of Sciences, \\ University of Alicante, 3690 Alicante, Spain; amartinezrodriguez@gcloud.ua.es \\ 6 Alicante Institute for Health and Biomedical Research (ISABIAL), 03010 Alicante, Spain \\ 7 Department of Applied Biology-Nutrition, Institute of Bioengineering, University Miguel Hernández, \\ 03202 Elche, Spain \\ 8 CIBER Fisiopatología de la Obesidad y Nutrición (CIBEROBN), Instituto de Salud Carlos III (ISCIII), \\ 28029 Madrid, Spain \\ * Correspondence: eroche@umh.es; Tel.: +34-965222029
}

Received: 28 October 2020; Accepted: 19 November 2020; Published: 22 November 2020

\begin{abstract}
Aging is associated with sarcopenia. The loss of strength results in decreased muscle mass and motor function. This process accelerates the progressive muscle deterioration observed in older adults, favoring the presence of debilitating pathologies. In addition, sarcopenia leads to a decrease in quality of life, significantly affecting self-sufficiency. Altogether, these results in an increase in economic resources from the National Health Systems devoted to mitigating this problem in the elderly, particularly in developed countries. Different etiological determinants are involved in the progression of the disease, including: neurological factors, endocrine alterations, as well as nutritional and lifestyle changes related to the adoption of more sedentary habits. Molecular and cellular mechanisms have not been clearly characterized, resulting in the absence of an effective treatment for sarcopenia. Nevertheless, physical activity seems to be the sole strategy to delay sarcopenia and its symptoms. The present review intends to bring together the data explaining how physical activity modulates at a molecular and cellular level all factors that predispose or favor the progression of this deteriorating pathology.
\end{abstract}

Keywords: aging; inflammation; oxidative stress; physical activity; sarcopenia; satellite cells

\section{Introduction}

Aging is associated with a loss of muscle strength (sarcopenia), leading to muscle mass loss, and resulting in decreased motor function [1]. This inevitable process leads older people to a progressive deterioration that can give rise to debilitating pathologies. Muscle mass loss leads to a decrease in quality of life, affecting their overall well-being and self-sufficiency [2]. Furthermore, sarcopenia is one of the multiple scenarios that contribute to the physiological and cognitive deterioration that appear during senescence progression. Furthermore, this degenerative process can exacerbate other underlying conditions, and ultimately cause a decrease in life expectancy [2,3].

General deterioration starts in the fifth decade of life and muscle loss is estimated at approximately $0.8 \%$ per year [4]. Other authors have estimated a gradual decline in skeletal muscle mass and strength 
of around $2 \%$ per year starting from the sixth decade of life [5]. The loss of muscle mass generally occurs due to the combination of two factors: muscle atrophy and the death of muscle cells, resulting both in loss of strength and muscle mass [6,7]. At a molecular level, an altered expression of protein synthesis and degradation factors have been observed [8]. In addition, sarcopenia reduces the cross-section of muscle fibers, due to their deterioration and loss of motor units [6,7]. Molecular mechanisms are not yet well defined, being an intense area of research [9-13].

The cause for sarcopenia onset is multifactorial, including neurological factors related to the loss of motor neurons, endocrine alterations resulting from the decreased or loss of hormone expression (such as testosterone or growth hormone (GH)), loss of muscle motor units, and finally, nutritional and lifestyle changes related to the adoption of sedentary habits [14-16]. Therefore, sarcopenia appears at a moment in life when physical activity decreases considerably [16], which could be one of the main triggers for the aforementioned events. There is an estimated $30 \%$ reduction in muscle mass in 80-year-old adults compared to 20-year-olds, and a $20 \%$ reduction in muscle area. Changes are observed both in fiber size and number, particularly type II fibers [17].

The lack of physical activity favors loss of muscle strength and mass $[18,19]$. Therefore, it can be considered that exercise protects against sarcopenia onset. However, there is little consensus as to what are the most recommended types of exercise in order to prevent or treat sarcopenia. On one side, aerobic physical activities such as walking and running improve maximum $\mathrm{O}_{2}$ consumption $\left(\mathrm{VO}_{2} \mathrm{max}\right)$. On the other hand, strength exercises help to improve muscle function and neuromuscular adaptation. Both exercise types are known to help decrease morbidity and mortality [20,21].

Inactivity is generally accompanied by an unbalanced diet rich in saturated fat, leading to increased fat deposits in the adipose tissue, liver, and muscle. Therefore, a high-fat diet can affect the composition and structure of skeletal muscle and satellite cells (SC). These cells are responsible for post-exercise muscle repair and regeneration processes. In non-obese individuals, skeletal muscle mass can account for $40 \%$ of total body weight, and contributes to optimal metabolic control, as well as regulate glucose and fatty acid circulating levels by modulating their absorption, usage, and storage [22]. In this context, excess fatty deposits affect the skeletal muscle by altering the hepatic growth factor (HGF) signaling pathway. This protein is attached to the extracellular matrix and is released after performing physical activity to repair the damage caused to the tissue during exercise, activating the SC. Therefore, the lack of physical activity in conjunction with an unbalanced diet are key factors that promote obesity and fat infiltration in muscle fibers and liver, altering the response of SC to HGF [23]. In addition, nitric oxide (NO) production increases with physical activity, and is a key signal in HGF activation. Therefore, the alteration of HGF signaling could result in a lack of SC activation and thus incorrect repair of muscle fibers and myogenesis [24-29]. Lack of physical exercise or disuse would lead to a decrease in NO production and subsequently affect the release of HGF from the extracellular matrix. This will in turn affect SC, which will remain in the G0 phase of the cell cycle. This process could worsen with aging, resulting in sarcopenic obesity associated with SC apoptosis [25].

Altogether, sarcopenia, or muscle mass loss, is a consequence of atrophy from disuse. However, the molecular mechanisms underlying this phenomenon are unknown. Alterations in the transcriptional regulation at the myocyte level have been proposed, triggering the activation of proteolytic processes [30]. One of the main pathways involved in the degradation of muscle proteins is the ubiquitin-proteasome system. This system plays a key role in controlling muscle fiber size. In this degradation mechanism, specific ligases bind ubiquitin to substrate proteins to prime them for proteolysis. Preliminary studies indicate that two ubiquitin ligases are upregulated when muscle atrophy appears; atrogin-1 and muscle-1 ring-finger protein-1 (MuRF-1). The expression of both proteins also increases in autophagy-related muscle degeneration processes. In addition, MuRF-1 may also be associated with mechanisms that cause neuromuscular junction alterations [31-33]. In this context, the Foxo family of transcriptional factors, which integrates signals generated by nutrient deprivation and stress situations, appears to be involved in the expression of genes related to the degradation systems of 
ubiquitin-proteasome and autophagy pathways, activating atrogin- 1 and MuRF- 1 and triggering the degradation of muscle proteins [34].

In addition, the role of myostatin should be considered. Myostatin (also known as GDF8) is an extracellular messenger of the transforming growth factor superfamily (TGF- $\beta$ ), which inhibits muscle growth. Myostatin controls the cell cycle, inhibiting the factors that regulate myogenesis [35]. The mechanism by which myostatin exerts its effects is similar to the rest of the TGF family members; that is, it forms tetrameric complexes consisting of two type I and 2 type II receptors [36]. In most cases, the ligand binds to type II receptors, subsequently recruiting type I receptors. The formation of this complex allows to phosphorylate serine and threonine residues in type I receptors through the kinase activity of type II receptors. In the case of myostatin, its activation requires the participation of ActRIIB (activin receptor IIB) and ALK4 (activin-like kinase 4), both of which are also involved in activin signaling [36]. The aged muscle expresses increased myostatin signaling and consequently initiates a process of progressive atrophy [36-38]. On the other hand, when myostatin signaling is blocked, this results in increased protein synthesis and muscle strength.

Therefore, there is a lack of consensus among the published studies, most likely due to the different experimental protocols applied. Nevertheless, it seems clear that the lack of SC activity (due to incorrect HGF signaling), together with an increase in intramuscular proteolytic activity (involving atrogin-1 and MuRF-1 activation) and an inhibited myogenesis (caused by increased myostatin signaling), play important roles in the decrease in strength and muscle mass during the aging process.

Altogether, sarcopenia seems to be a multifactorial process (Table 1), which will be further detailed in this review. As there is currently no cure for sarcopenia, the most efficient strategy is to take preventive measures to delay its progression. There is increasing evidence that maintaining physical activity throughout life delays its onset. Therefore, evidence regarding the role of physical activity in delaying sarcopenia and its symptoms will also be presented.

Table 1. Etiopathological factors around sarcopenia.

\begin{tabular}{l} 
Malnutrition: \\
Increased intramuscular saturated fat deposition. \\
Increased risk of atherosclerosis. \\
\hline Alterations in muscle structure: \\
Lower activity of satellite cells caused by defects in HGF signaling. \\
Decrease in motor units caused by intramuscular proteolysis activation. \\
Presence of oxidative stress. \\
\hline Altered muscle signaling: \\
Activation of myostatin (GDF8) pathway. \\
Decreased presence of anabolic hormones: Testosterone, growth hormone. \\
Neuronal dysfunction. \\
Increase in pro-inflammatory cytokines: TNF- $\alpha, \mathrm{IL}-1 \beta$, and IL-6. \\
\hline Decreased physical activity. \\
\hline$\quad$ Abbreviations used: IL, interleukin; TNF, tumor necrosis factor.
\end{tabular}

\section{Satellite Cells}

SC are located between the basal lamina and sarcolemma within the muscle fibers, being in a state of mitotic quiescence and, at the metabolic level, in a state of semi-latency [24]. These cells are activated and proliferate in response to stimuli such as physical exercise, injuries, or mechanical stress. In this context, SC are the main contributors to muscle maintenance, repair, and growth [25-27]. In order to carry out muscle regeneration growth or repair, SC must follow a three-step process [28,29,39,40]:

1. Activation from their quiescence state.

2. Proliferation by entry into the cell cycle.

3. Differentiation and fusion to form multinucleated myotubes, by activating protein synthesis. 
SC activation involves a signaling route in which calmodulin-Ca binds to nitric oxide synthase (NOS), which results in NO production. This pathway is activated in the muscle in response to exercise, injury, denervation or trauma associated with intense muscle activity [26,41]. As previously mentioned, NO favors the release of HGF bound to the extracellular matrix by mechanisms yet to be elucidated. In turn, HGF promotes SC activation [42-44]. On the other hand, the inhibition of NO production could lead to a lower release of HGF, and therefore less activation of SC [43]. The SC activation results in muscle fiber regeneration and repair, through SC fusion with myoblasts or activating their proliferation [45].

Throughout the aging process, many of the factors that promote the activation of SC are greatly diminished or even absent. Thus, the SC activation pathway initiated by NO appears to be less efficient in the elderly. The study conducted by Leiter et al. [46] demonstrated that SC of young mice are activated immediately after a stimulus, while SC of older mice may have a 24-h activation delay. Similarly, mechanical stimuli response is also affected. For example, a longer stretching of muscle fiber must be performed in order to activate the SC [26,46]. Otherwise said, more intense stimuli are required for SC activation in elder animals. Interestingly, in atrophy by disuse, muscle fibers acquire characteristics very similar to aged fibers, leading both situations to significant levels of muscle disability $[45,46]$. Therefore, aging is associated with a significant decrease in the number of active SC.

\section{Oxidative Stress}

As previously mentioned, sarcopenia involves the participation of various processes that need to be analyzed in detail in order to have a global view of the problem. One of these refers to the presence of oxidative stress. Numerous scientific studies have established, in a well-documented way, the role played by reactive oxygen (ROS) and nitrogen species (RNS), collectively known as RONS, in numerous biological and pathological processes. ROS include superoxide anion $\left(\mathrm{O}_{2}{ }^{-}\right)$, hydroxyl radical (HO), along with non-radical species such as hydrogen peroxide $\left(\mathrm{H}_{2} \mathrm{O}_{2}\right)$. Among RNS are mainly $\mathrm{NO}$ and peroxinitrite anion $\left(\mathrm{ONOO}^{-}\right)$, both free radicals. The most important production of ROS in muscle cells is located in mitochondria. Nevertheless, NO is mainly produced by NOS isoenzymes, in which arginine as a substrate is transformed into citrulline [47-50].

The most widely accepted theory about aging is that this process involves an uncontrolled participation of free radicals. ROS, which appear as collateral products of mitochondrial metabolism, would cause progressive damage to key cell macromolecules (lipids, proteins, and DNA), altering both their structure and function. These oxidized molecules would accumulate and spread oxidative damage due to a malfunction of antioxidant and repair systems. Due to its high metabolic rate, the skeletal muscle is especially susceptible. For this reason, muscle cells of older individuals are predisposed to accumulate oxidized molecules and therefore exposed often to oxidative stress, compared to young individuals. A plausible hypothesis to explain the lack of response to oxidative stress observed in aged muscle tissue could be its inability to recognize redox signaling molecules, necessary to activate genes that encode antioxidant and repair proteins [49].

In this context, the skeletal muscle is the most abundant tissue in the human body, and where the majority of the oxidation metabolic reactions occur. In addition, the muscles easily adapt in response to different stimuli, including an excess of RONS production [51]. Since this response is mitigated in aged muscle tissue, we can hypothesize that the overproduction of RONS together with a decreased response from antioxidant systems could contribute to the appearance of sarcopenia and delay of muscle regeneration in the elderly [52].

Excessive generation of RONS causes alterations related to energy metabolism and muscle contraction function, both in the coupling excitation-contraction, in the ion homeostasis, as well as in the contraction/relaxation process of muscle fibers [53,54]. Thus, in the muscle, the highest demand for energy is produced when muscle contractions are activated. The production of energy in the mitochondria produces radical $\mathrm{O}_{2}{ }^{-}$, as a collateral product of the electron transport chain, being able to produce other RONS [50]. However, RONS produced during muscle contraction can trigger an 
adaptive response, inducing the activation of transcription factors that modulate the gene expression of antioxidant enzymes, such as superoxide dismutase, involved in $\mathrm{O}_{2}{ }^{-}$elimination. Therefore, RONS can act as mediators in various cell signaling pathways that would culminate in cellular responses to both physiological and pathological situations. Therefore, cells need to maintain the balance between the generation of RONS and its elimination. An imbalance towards increased production of RONS at the intracellular level could trigger a situation of oxidative stress. Therefore, cellular redox regulation in the skeletal muscle is critical for its homeostasis [55].

In addition, NADPH-oxidase, located in the plasma membrane and at the level of the transverse tubules of the skeletal muscle, is a key element in redox signaling. NADPH-oxidase is formed by several subunits, distributed between the cytoplasm and the plasma membrane in inactive cells. The enzyme catalyzes NADPH oxidation to $\mathrm{NADP}^{+}$, using molecular oxygen as substrate and leading to $\mathrm{O}_{2}{ }^{-}$ production. Several studies show that skeletal muscle cells release $\mathrm{O}_{2}{ }^{-}$to extracellular space during contraction [55-57]. This radical should play an instrumental role in redox signaling, modulating cytoprotective responses that help to maintain cellular viability [58,59]. Therefore, redox signaling errors should be considered as key molecular factors in sarcopenia development.

\section{Neuronal Factors}

Muscle mass loss partly explains the loss of strength related to age, giving relevance to the concept of muscle quality [60]. However, several neurological factors are also partly responsible for the loss of strength [61].

Muscle contraction is a complex process coordinated by various interrelated brain structures. In order to carry out this motor control, the motor area must be integrated into complex circuits with the prefrontal cortex, basal ganglia, and cerebellum. Unfortunately, this set of structures suffers to a greater extent the consequences of the aging process, becoming atrophic with time [62].

At the spinal cord level, two processes limit the structure necessary for muscle contraction. On one hand, starting at the age of 60, around a quarter to half of the motor neurons are lost [63]. Second, there is a reduction in axonal size and its myelinization at the level of the peripheral nerve [64], with the consequent loss of nerve conduction velocities [65].

Motor neuron loss reduces the estimated number of motor units determined by electromyography [65]. This loss of motor neurons leads to the denervation of muscle fibers. As a result, neural plasticity is activated, remodeling the innervation of motor units while increasing their size during the process. This helps to maintain muscle function to some extent. Therefore, the loss of strength occurs later and does not coincide with the decreased motor units [65]. For example, Urbanchek et al. [66] observed in rats that only $11 \%$ of the strength decrease observed was due to the denervated fibers, suggesting that additional factors contribute to the development of sarcopenia. On the other hand, the capacity and duration of the opening of the sodium channels located in the motor plate is affected with age. This process results in strength loss and fatigue [67].

In addition, the loss of motor neurons appears to occur more often in the larger motor neurons, which are the largest motor units that connect to fast fibers [61]. This focus implies a loss of fast muscle fibers, increasing reinnervation by small motor neurons that turn fast muscle fibers into slow ones. This process explains the different percentages in the types of muscle fibers observed with age [68].

Finally, the expression of neurotrophic factors related to the nervous system, such as brain-derived neurotrophic factor (BDNF), a neurotrophin associated with synaptic plasticity and cell survival, are reduced with age [69]. BDNF has been described to be involved in the metabolic processes of peripheral systems such as muscle fibers. BDNF release is stimulated by skeletal muscle contraction, improving fat oxidation metabolism and muscle fiber functionality during the contraction process [70]. In addition, BDNF could stimulate the DNA repair process by activating the cyclic-AMP response element binding protein (CREB), although the effects of BDNF signaling on skeletal muscle are not yet clear [70]. Nevertheless, it has been observed that, in the absence of BDNF, the muscle loses its ability to synthesize proteins, and reduces myogenic regulatory factors, linked to muscle regeneration and 
development, leading to muscular atrophy [71]. In this context, the production and release of brain BDNF increases with physical activity [72-74]. This process could improve the homeostasis of the central nervous system and the skeletal muscle, delaying the onset of sarcopenia $[70,75]$.

\section{Inflammatory Processes}

The immune system plays an important role in skeletal muscle regeneration. Sarcopenia leads to a reduction in muscle regeneration capacity caused by local inflammatory mechanisms (especially due to eccentric exercises). This induces an alteration of the neuro-hormonal response, which results in an imbalance in protein synthesis and degradation. This is mainly mediated by interleukin-1 $\beta$ (IL-1 $\beta$ ), tumor necrosis factor- $\alpha$ (TNF- $\alpha$ ), interleukin-15 (IL-15), and insulin-like growth factor-1 (IGF-1). The activation of the inflammatory process results in a decrease in the number of SC [67]. Therefore, an important part of the changes that occur during aging, including immuno-senescence, can be explained as a consequence of the imbalance between pro-inflammatory and anti-inflammatory processes, resulting in a chronic low-grade muscle pro-inflammatory state, which in the long term can progressively lead to muscle deterioration [76].

TNF- $\alpha$ activates local vascular endothelial cells, which causes NO release that in turn increases vascular permeability, allowing the passage of pro-inflammatory cells and triggering inflammation. Therefore, TNF- $\alpha$ and its soluble receptors are important markers of muscle loss and strength in the aged muscle during the latent inflammatory process [76]. Thus, an increased plasma concentration of TNF- $\alpha$ correlates with lower muscle mass and strength, contributing to sarcopenia onset. Increased concentration of TNF- $\alpha$ is also related to the activation of apoptosis in muscle cells [77].

Another key cytokine present in senescence processes is interleukin-6 (IL-6). High plasma levels of this cytokine correlate with fatigue and disability, associated with muscle destruction [78]. Therefore, it is believed that IL- 6 circulating levels are intimately associated with decreased age-related muscle function, and loss of mass and strength. In this sense, the release of IL- 6 and TNF- $\alpha$ and its increase in serum would indicate a general pro-inflammatory state that could be active throughout the aging process, favoring the onset of sarcopenia [79].

Considering cytokines as targets for therapeutic strategies in sarcopenia, certain treatments have been developed that act upon the TNF- $\alpha$ signaling pathways. The results have not been very promising, hence processes activated by these cytokines have been investigated as alternative targets, for example the inducible form of NOS (iNOS) [80]. In this context, the effects of cytokine-induced oxidative stress depend on increased iNOS expression. Inhibitors of iNOS activity have demonstrated a clear efficiency to prevent symptoms of muscle wasting [81].

As previously mentioned, the aging process is related to increases in pro-inflammatory cytokines such as IL- 6 and TNF- $\alpha$, resulting in an increased production of acute-phase reactive proteins by the liver, such as C-reactive protein (CRP) or $\alpha 1$-antichimotrypsin (ACT). High levels of IL- 6 and/or CRP are associated with a decrease in physical performance and a greater degree of disability [82]. On the other hand, the acute muscular regenerative response is modulated by macrophages. In this sense, it has been observed that a greater degree of neutrophilia, which affect the appropriate temporal macrophage phenotype transition, is associated with a decrease or even the inhibition of muscle regenerative capacity [83].

Finally, it has also been observed that the evolution of sarcopenia is accelerated in the presence of chronic inflammatory pathological states such as those observed in insulin resistance, atherosclerosis, and Alzheimer disease. Older adults are more prone to develop these pathologies compared with their younger counterparts under similar environmental conditions. Chronic inflammation states observed in these pathologies present an increase in circulating pro-inflammatory cytokines, increased presence of dysfunctional T-regulatory cells and a T-cell-senescent phenotype. These alterations compromise the immune response, resulting in a condition known as "immune-senescence" or "inflammaging". In this context, increased levels of ACT have been shown to be associated with Alzheimer's disease [82]. Another example is provided by older patients with HIV in which chronic inflammation favors the 
development of other pathologies, including cardiovascular, kidney or liver disease, cancers, certain neurological diseases and "geriatric syndromes", including sarcopenia, frailty, and falls [84].

\section{New Perspectives to Focus Sarcopenia Management}

Since a cure for sarcopenia does not exist, all studies on delaying its onset and lessening its symptoms have one thing in common: physical activity. Sedentary lifestyles in older adults cause skeletal muscle inactivity, which accelerates strength loss and therefore muscle atrophy. The recovery of muscle mass would be difficult, since efficient protocols to reach an optimal previous situation have not been implemented $[85,86]$. Muscle disuse would also reduce the rate of postprandial amino acid muscle absorption, resulting in a decrease in myofibrillary protein synthesis [87,88]. In this negative scenario, exercise would compensate for the harmful effects caused by aging such as sarcopenia, modulating all the factors involved: oxidative stress, neural dysfunction, and inflammation (Figure 1). In addition, exercise is beneficial to prevent obesity and mitochondrial dysfunction, which enhance sarcopenia progression.

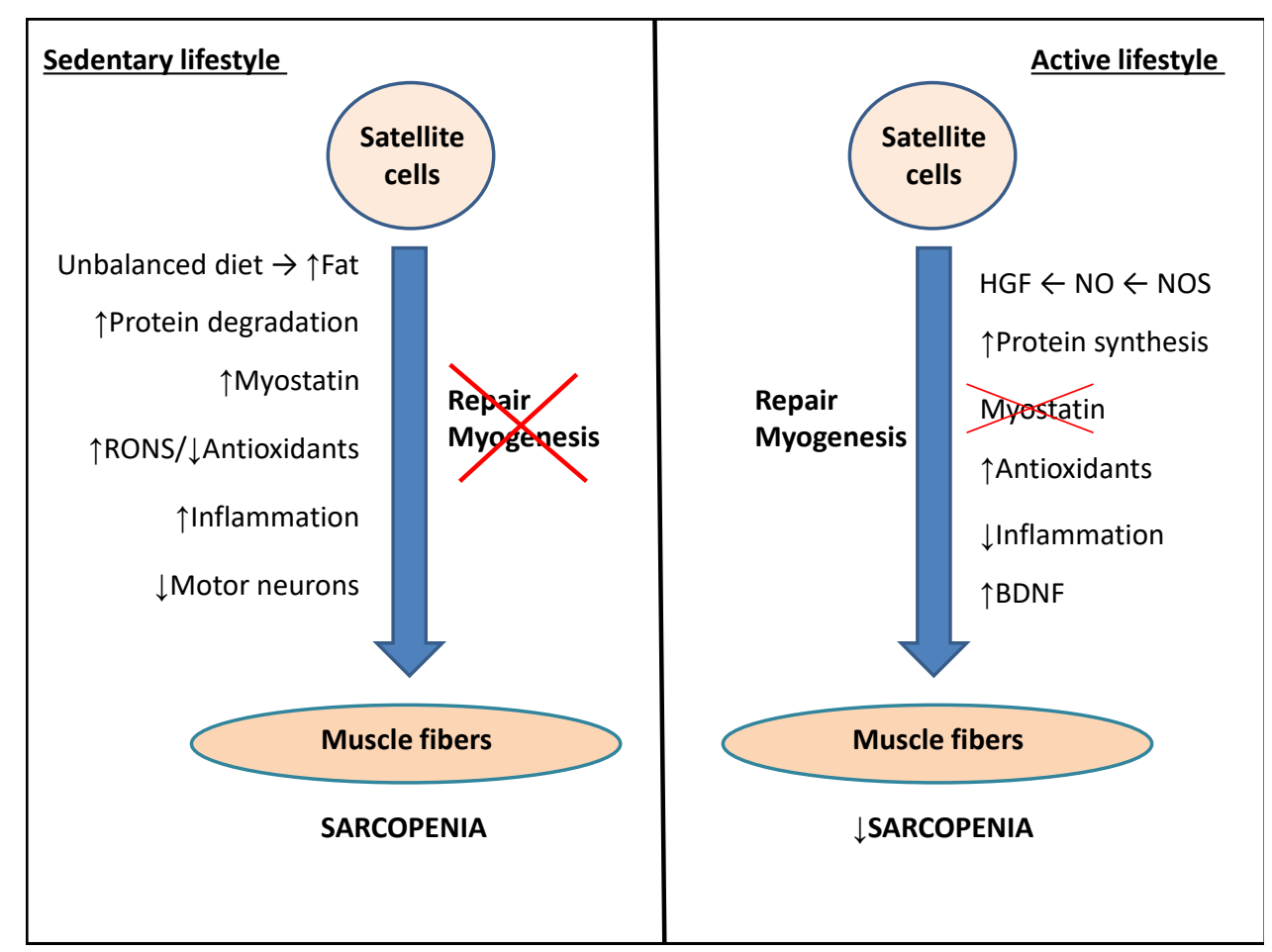

Figure 1. Scheme of the main factors predisposing to sarcopenia and the role of physical activity in delaying this process. See text for more details. Abbreviations and symbols used: BDNF, brain-derived neurotrophic factor; HGF, hepatic growth factor; NO, nitric oxide; NOS, nitric oxide synthase; RONS, reactive oxygen and nitrogen species; $(\uparrow)$ increased; $(\downarrow)$ decreased.

\subsection{Role of Physical Activity in Modulating Oxidative Stress to Delay the Sarcopenia Associated with Aging}

Physical activity has been shown to cause changes in antioxidant enzyme levels, both in acute bouts and over time. As discussed above, these modifications can be triggered by ROS generated during exercise, which are key elements for the onset of muscle adaptation to delay sarcopenia. Thus, post-exercise ROS in muscle cells can act as triggers or repressors for a wide variety of genes [55]. In this context, the skeletal muscle has the ability to adapt to certain stimuli or stressors caused during concentric or eccentric muscle traction, stretching or contraction.

A key issue would be to identify the most efficient exercise type in delaying sarcopenia. Resistance exercises seem to be associated with a lower use of aerobic metabolism and oxidative processes when compared to demanding aerobic exercises [50]. On the other hand, aerobic training increases NO levels, 
as a result of increased NOS. This, in turn, favors blood flow in muscle fibers due to the vasodilation produced. This process indirectly protects the muscle from pro-oxidant effects that appear during exercise, allowing for a greater arrival of circulating antioxidants [89].

As previously mentioned, many studies have proposed that ROS production during exercise constitutes a natural stimulus that leads to an improvement of antioxidant defenses and decreased activation of the inflammatory pathways, resulting in a greater resistance of organisms to free radicals $[90,91]$. This strongly indicates that, despite new discoveries and the development of new drugs, non-pharmacological therapies such as physical exercise and nutritional support could be considered the basis for the prevention and treatment of muscle abnormalities associated with age.

Adaptive changes in antioxidant protective processes have been detected in both endurance and resistance exercises, such as increased activity of catalase (CAT) and superoxide dismutase (SOD). The increase in CAT and SOD are induced by an increased production of $\mathrm{H}_{2} \mathrm{O}_{2}$ and $\mathrm{O}_{2}{ }^{-}$, respectively, during exercise [91]. On the other hand, glutathione peroxidase (GPX) is an enzyme with five isoforms that catalyzes the reduction of $\mathrm{H}_{2} \mathrm{O}_{2}$ into $\mathrm{H}_{2} \mathrm{O}$, as well as organic hydroperoxides (ROOH) and hydroxylated derivatives (ROH). This antioxidant enzyme uses reduced glutathione (GSH) that is transformed into oxidized glutathione (GSSG). GSSG cannot be released to the cytosol and must be reduced back to GSH in the mitochondrial matrix. Meanwhile, GSH levels in the skeletal muscle appear to be constant [92] while GSSG levels increase with age. Subsequently, the GSH/GSSG ratio decreases significantly, suggesting that aging could cause significant alterations in glutathione balance in skeletal muscle [93].

Altogether, oxidative stress parameters show that exercise is able to promote a protective and adaptive effect against increased ROS, reducing the risks of cell damage. This can be achieved with aerobic as well as resistance training routines $[74,91,93]$ and this could be a beneficial strategy to delay sarcopenia.

\subsection{Role of Physical Exercise in Modulating Satellite Cell Activity to Delay Sarcopenia Associated with Aging}

Exercise increases the expression of the neuronal form of NOS (nNOS) in the muscle, leading to the activation of SC. Furthermore, exercise decreases the expression of myostatin in muscle fibers, as observed in individuals that followed an exercise plan, while this was not observed in a sedentary control group. All of this leads to the thought that SC can be activated mechanically, depending on age and muscle type [3]. With regard to the expression of myostatin, it has been observed that exercise decreases the expression of this muscle growth-inhibiting messenger, regardless of gender or age, although certain exceptions have been observed in older women [94].

In a study with 8-month-old mice, SC activation was found to be triggered by NO produced by nNOS in the quadriceps muscle. Activation occurred exclusively in this muscle when it was exercised, while passive quadriceps did not display SC activation. However, muscle type should be considered in this context, since muscles of the lower body do not respond in the same way as those in the upper body segment [42,95]. In addition, no increased nNOS activity was observed in aging muscles, explaining the poor activation of SC with age. Therefore, all this evidence might suggest that the activation of SC and nNOS expression would depend specifically on the type of muscle, the workload applied and the individual's age.

Research evidence indicates that resistance training promotes SC activation and proliferation. The SC response to exercise occurs in both young and old individuals, although the level of response differs among the age groups [96]. Also, it has been observed that certain individuals have a higher SC response than other, leading to the thought that there are responders and non-responders, possibly depending on genetic factors $[97,98]$.

Certain research has quantified the increase in SC in the skeletal muscle after a period of resistance training, with a $19 \%$ increase after 30 working days and $31 \%$ after 90 days of training. This proliferation of SC coincides with an increase in mRNA of two cell cycle markers: cyclin-D1 and p21 [99]. In addition, changes in SC following adaptations caused by exercise are associated with a decrease in $\mathrm{O}_{2}$ levels in 
muscle cells and increased levels of vascular endothelial growth factor (VEGF) and epidermal growth factor (EGF), all of which can influence SC proliferation induced by resistance training $[100,101]$.

Another key factor that will affect SC proliferation is the decrease in telomere length throughout life. This leads to the impossibility of SC division, once telomeres have reached a critical length. Interestingly, training routines accompanied by moderate oxidative stress can positively influence a compatible length of telomeres, both in leukocytes and skeletal muscle $[102,103]$. The presented evidence strongly indicates that a regulated activity of SC is going to be critical for sarcopenia delay, due to the role they play in the adaptation to exercise, strength maintenance, and functionality of the skeletal muscle.

\subsection{Role of Nutrition to Delay Sarcopenia Associated with Aging}

Recent publications have shown how certain nutritional interventions, such as high protein or essential amino acid and leucine ingestion, in combination with resistance training, may help to delay the fiber loss observed in sarcopenia [104-108]. Muscle protein could be considered as a key mechanical component and an amino acid reserve for several body functions. The amount and quality of protein ingested in diet is a very important factor for muscle mass anabolism. Meanwhile, dietary recommendations for protein consumption in adults are established at around $0.8 \mathrm{~g} / \mathrm{kg} / \mathrm{day}$, while the European Society for Clinical Nutrition and Metabolism (ESPEN) recommends over $1 \mathrm{~g} / \mathrm{kg} /$ day (up to $1.5 \mathrm{~g} / \mathrm{kg} /$ day) for older adults in order to delay the increased risk of sarcopenia [104-107,109].

However, the elderly usually present a low nutrient intake (including proteins) due to several reasons, such as physical disability and lack of appetite, being exacerbated by a poor access to quality foods due to economic limitations $[3,105,106]$. In addition, certain individuals reduce or eliminate protein intake, especially from meat, due to chewing and swallowing difficulties. This leads them on many occasions to choose other foods with less protein content or poor amino acid quality. For this reason, it is necessary to present alternative high-quality protein sources, such as eggs or fish that are easy to chew; as well as modifications in culinary preparations, in order to increase the proportion of soft textures [104-106]. In addition, to achieve the daily recommended protein intake, older adults need to eat protein at every meal to promote muscle anabolism. Avoiding these recommendations can give rise to chronic protein malnutrition, which has been shown to be associated with an approximately four-fold increased risk of developing severe sarcopenia [3,104].

\subsection{Role of Biological Rhythms to Delay Sarcopenia Associated with Aging}

Recent evidence suggests that the circadian clock is instrumental in promoting skeletal muscle growth and body homeostasis. Therefore, the maintenance of biological rhythms could be essential to prevent or delay sarcopenia. Although the circadian rhythms are generally regulated by the cycles of light/darkness, there are other secondary agents, such as physical activity, that can contribute to its modulation. In this sense, the molecular clock is essential in the circadian coordination of specific genes expressed in the skeletal muscle, such as those controlling structure, function, and metabolism. Maintaining a circadian muscular rhythm favors muscle growth, while clock disruption favors sarcopenia [110].

\section{Conclusions}

From a public health perspective, physical exercise can be considered as a non-pharmacological strategy to improve the quality of life of the elderly and delay sarcopenia onset [111]. Currently, there are several lines of research to determine the biochemical and physiological mechanisms involved in age-induced muscle deterioration. The implications in the myolysis process are so varied that it is difficult to define what are the determining factors and reactions that converge in these processes. However, it seems right to say that in almost all of these mechanisms, exercise acts as a key facilitator of muscle regeneration and repair processes, delaying sarcopenia. 
Exercise benefits skeletal muscle homeostasis through changes in muscle fiber composition that results in improved muscle performance. As commented throughout the present review, exercise helps modulate sarcopenia progression by controlling oxidative stress and SC activity. Under these principles, an effective physical intervention would improve muscle strength and quality. In addition, physical activity protocols should be performed in conjunction with an adequate diet to avoid inflammation, and taking in consideration the circadian rhythm. Under these principles and following the principles of training, the programs should include 2-3 days per week of strength training to improve the response and muscular adaptations. Aerobic programs to maintain cardiovascular function can also be added alternatively throughout the rest of the week. One day for resting and mental recovery is highly recommended. Resistance as well as endurance programs must follow the recommendations of a professional that will prepare the exercise protocols adapted to each particular individual taking in consideration motor limitations, intensity and time involved.

Author Contributions: All authors have read and agreed to the published version of the manuscript.

Funding: This study was supported by ISABIAL (grant number 190290) and the Official Funding Agency for Biomedical Research of the Spanish Government, Institute of Health Carlos III (ISCIII) through CIBEROBN (CB12/03/30038), which is co-funded by the European Regional Development Fund.

Acknowledgments: CIBEROBN is an initiative of Instituto de Salud Carlos III, Spain.

Conflicts of Interest: The authors declare no conflict of interest. The funders had no role in the design of the study; in the collection, analyses, or interpretation of data; in the writing of the manuscript, or in the decision to publish the results.

\section{Abbreviations}

\begin{tabular}{|c|c|}
\hline ACT & $\alpha 1$-antichymotrypsin \\
\hline ACtRIIB & Activin receptor IIB \\
\hline ALK4 & Activin-like kinase 4 \\
\hline BDNF & Brain-derived neurotrophic factor \\
\hline CAT & Catalase \\
\hline CREB & Cyclic-AMP response element binding protein \\
\hline CRP & C-reactive protein \\
\hline EGF & Epidermal growth factor \\
\hline GH & Growth hormone \\
\hline GPX & Glutathione peroxidase \\
\hline GSH & Reduced glutathione \\
\hline GSSG & Oxidized glutathione \\
\hline $\mathrm{H}_{2} \mathrm{O}_{2}$ & Hydrogen peroxide \\
\hline HGF & Hepatic growth factor \\
\hline HIV & Human immunodeficiency virus \\
\hline $\mathrm{HO}$. & Hydroxyl radical \\
\hline IGF-1 & Insulin-like growth factor- 1 \\
\hline IL & Interleukin \\
\hline iNOS & Inducible form of nitric oxide synthase \\
\hline LD & Linear dichroism \\
\hline MuRF-1 & Muscle-1 ring-finger protein-1 \\
\hline nNOS & neuronal form of nitric oxide synthase \\
\hline NO & Nitric oxide \\
\hline NOS & Nitric oxide synthase \\
\hline $\mathrm{O}_{2} \cdot-$ & Superoxide anion \\
\hline $\mathrm{ONOO}^{-}$ & Peroxinitrite anion \\
\hline RNS & Reactive nitrogen species \\
\hline $\mathrm{ROH}$ & Organic hydroxylated derivatives \\
\hline ROS & Reactive oxygen species \\
\hline RONS & Reactive oxygen and nitrogen species \\
\hline
\end{tabular}




$\begin{array}{ll}\text { ROOH } & \text { Organic hydroperoxides } \\ \text { SC } & \text { Satellite cells } \\ \text { SOD } & \text { Superoxide dismutase } \\ \text { VEGF } & \text { Vascular endothelial growth factor } \\ \text { TGF- } \beta & \text { Transforming growth factor- } \beta \\ \text { TNF- } \alpha & \text { Tumor necrosis factor- } \alpha\end{array}$

\section{References}

1. Cruz-Jentoft, A.J.; Sayer, A.A. Sarcopenia. Lancet 2019, 393, 2636-2646. [CrossRef]

2. Rolland, Y.; Van Kan, G.A.; Gillette-Guyonnet, S.; Vellas, B. Cachexia versus sarcopenia. Curr. Opin. Clin. Nutr. Metab. Care 2011, 14, 15-21. [CrossRef] [PubMed]

3. Cruz-Jentoft, A.J.; Baeyens, J.P.; Bauer, J.M.; Boirie, Y.; Cederholm, T.; Landi, F.; Martin, F.C.; Michel, J.-P.; Rolland, Y.; Schneider, S.M.; et al. Sarcopenia: European consensus on definition and diagnosis: Report of the European Working Group on Sarcopenia in Older People. Age Ageing 2010, 39, 412-423. [CrossRef] [PubMed]

4. Phillips, S. Physiologic and molecular bases of muscle hypertrophy and atrophy: Impact of resistance exercise on human skeletal muscle (protein and exercise dose effects). Appl. Physiol. Nutr. Metab. 2009, 34, 403-410. [CrossRef]

5. Hughes, V.A.; Frontera, W.R.; Roubenoff, R.; Evans, W.J.; Singh, M.A. Longitudinal changes in body composition in older men and women: Role of body weight change and physical activity. Am. J. Clin. Nutr. 2002, 76, 473-481. [CrossRef]

6. Well, S. Cellular and molecular basis of age-related sarcopenia. Can. J. Appl. Physiol. 2002, 27, $19-41$. [CrossRef]

7. Kamel, H.K. Sarcopenia and aging. Nutr. Rev. 2003, 61, 157-167. [CrossRef]

8. Dickinson, J.M.; Volpi, E.; Rasmussen, B.B. Exercise and nutrition to target protein synthesis impairments in aging skeletal muscle. Exerc. Sport Sci. Rev. 2013, 41, 216-223. [CrossRef]

9. Anderson, J.E.; Zhu, A.; Mizuno, T.M. Nitric oxide treatment attenuates muscle atrophy during hind limb suspension in mice. Free Radic. Biol. Med. 2018, 115, 458-470. [CrossRef]

10. Sakellariou, G.K.; Pearson, T.; Lightfoot, A.P.; Nye, G.A.; Wells, N.; Giakoumaki, I.I.; Vasilaki, A.; Griffiths, R.D.; Jackson, M.J.; McArdle, A. Mitochondrial ROS regulate oxidative damage and mitophagy but not age-related muscle fiber atrophy. Sci. Rep. 2016, 6, 33944. [CrossRef] [PubMed]

11. Palomero, J.; Jackson, M.J. Redox regulation in skeletal muscle during contractile activity and aging. J. Anim. Sci. 2010, 88, 1307-1313. [CrossRef] [PubMed]

12. Devries, M.C.; Breen, L.; Von Allmen, M.; McDonald, M.J.; Moore, D.R.; Offord, E.A.; Horcajada, M.-N.; Breuillé, D.; Phillips, S.M. Low-load resistance training during step-reduction attenuates declines in muscle mass and strength and enhances anabolic sensitivity in older men. Physiol. Rep. 2015, 3, e12493. [CrossRef] [PubMed]

13. Vilela, T.C.; Effting, P.S.; Dos Santos Pedroso, G.; Farias, H.; Paganini, L.; Rebelo-Sorato, H.; Tiescoski Nesi, R.; Moraes de Andrade, V.; Aurino de Pinho, R. Aerobic and strength training induce changes in oxidative stress parameters and elicit modifications of various cellular components in skeletal muscle of aged rats. Exp. Gerontol. 2018, 106, 21-27. [CrossRef] [PubMed]

14. Wozniak, A.C.; Anderson, J.E. The dynamics of the nitric oxide release-transient from stretched muscle cells. Int. J. Biochem. Cell Biol. 2009, 41, 625-631. [CrossRef] [PubMed]

15. Gielen, E.; O’Neill, T.W.; Pye, S.R.; Adams, J.E.; Wu, F.C.; Laurent, M.R.; Claessens, F.; Ward, K.A.; Boonen, S.; Bouillon, R.; et al. Endocrine determinants of incident sarcopenia in middle-aged and elderly European men. J. Cachexia Sarcopenia Muscle 2015, 6, 242-252. [CrossRef] [PubMed]

16. Cruz-Jentoft, A.J.; Bahat, G.; Bauer, J.; Boirie, Y.; Bruyère, O.; Cederholm, T.; Cooper, C.; Landi, F.; Rolland, Y.; Aihie-Sayer, A.; et al. Sarcopenia: Revised European consensus on definition and diagnosis. Age Ageing 2019, 48, 16-31. [CrossRef] 
17. Fielding, R.A.; Vellas, B.; Evans, W.J.; Bhasin, S.; Morley, J.E.; Newman, A.B.; Abellan van Kan, G.; Andrieu, S.; Bauer, J.; Breuille, D.; et al. Sarcopenia: An undiagnosed condition in older adults. Current consensus definition: Prevalence, etiology, and consequences. International Working Group on Sarcopenia. J. Am. Med. Dir. Assoc. 2011, 12, 249-256. [CrossRef]

18. Kortebein, P.; Ferrando, A.; Lombeida, J.; Wolfe, R.; Evans, W.J. Effect of 10 days of bed rest on skeletal muscle in healthy older adults. JAMA 2007, 297, 1772-1774. [CrossRef]

19. Lee, J.S.W.; Auyeung, T.-W.; Kwok, T.; Lau, E.M.C.; Leung, P.-C.; Woo, J. Associated factors and health impact of sarcopenia in older chinese men and women: A crosss-sectional study. Gerontology 2007, 53, 404-410. [CrossRef]

20. Sheffield-Moore, M.; Yeckel, C.W.; Volpi, E.; Wolf, S.E.; Morio, B.; Chinkes, D.L.; Paddon-Jones, D.; Wolfe, R.R. Postexercise protein metabolism in older and younger men following moderate-intensity aerobic exercise. Am. J. Physiol. Endocrinol. Metab. 2004, 287, E513-E522. [CrossRef]

21. Charifi, N.; Kadi, F.; Féasson, L.; Denis, C. Effects of endurance training on satellite cell frequency in skeletal muscle of old men. Muscle Nerve 2003, 28, 87-92. [CrossRef] [PubMed]

22. Baumgartner, R.N.; Waters, D.L. Sarcopenia and sarcopenic-obesity. In Principles and Practice of Geriatric Medicine; Pathy, M.S.J., Sinclair, A.J., Morley, J.E., Eds.; John Wiley and Sons Ltd.: Chichester (West Sussex), UK, 2006; pp. 909-934.

23. Tam, C.S.; Covington, J.D.; Bajpeyi, S.; Tchoucalova, Y.; Burk, D.; Johannsen, D.L.; Zingaretti, C.M.; Cinti, S.; Ravussin, E. Weight gain reveals dramatic increases in skeletal muscle extracellular matrix remodelling. J. Clin. Endocrinol. Metab. 2014, 99, 1749-1757. [CrossRef] [PubMed]

24. Anderson, J.E.; Wozniak, A.C. Satellite cell activation on fibers: Modeling events in vivo-An invited review. Can. J. Physiol. Pharm. 2004, 82, 300-310. [CrossRef] [PubMed]

25. Wozniak, A.C.; Anderson, J.E. Single-fiber isolation and maintenance of satellite cell quiescence. Biochem. Cell Biol. 2005, 83, 674-676. [CrossRef]

26. Wozniak, A.C.; Pilipowicz, O.; Yablonka-Reuveni, Z.; Greenway, S.; Craven, S.; Scott, E.; Anderson, J.E. C-Met expression and mechanical activation of satellite cells on cultured muscle fibers. J. Histochem. Cytochem. 2003, 51, 1437-1445. [CrossRef]

27. Sharples, A.P.; Hughes, D.C.; Deane, C.S.; Saini, A.; Selman, C.; Stewart, C.E. Longevity and skeletal muscle mass: The role of IGF signalling, the sirtuins, dietary restriction and protein intake. Aging Cell 2015, 14, 511-523. [CrossRef]

28. Bockhold, K.J.; Rosenblatt, J.D.; Partridge, T.A. Aging normal and dystrophic mouse muscle: Analysis of myogenicity in cultures of living single fibers. Muscle Nerve 1998, 21, 173-183. [CrossRef]

29. Kadi, F.; Charifi, N.; Denis, C.; Lexell, J. Satellite cells and myonuclei in young and elderly women and men. Muscle Nerve 2004, 29, 120-127. [CrossRef]

30. Sandri, M.; Sandri, C.; Gilbert, A.; Skurk, C.; Calabria, E.; Picard, A.; Walsh, K.; Schiaffino, S.; Lecker, S.H.; Goldberg, A.L. Foxo transcription factors induce the atrophy-related ubiquitin ligase atrogin-1 and cause skeletal muscle atrophy. Cell 2004, 117, 399-412. [CrossRef]

31. Gumucio, J.P.; Mendias, C.L. Atrogin-1, MuRF-1, and sarcopenia. Endocrine 2013, 43, 12-21. [CrossRef]

32. Cunha, J.E.; Medeiros-Barbosa, G.; Tomé de Souza-Castro, P.A.; Ferreira-Luiz, B.L.; Arcari-Silva, A.C.; Russo, T.L.; Vasilceac, F.A.; Mattar-Cunha, T.; Queiróz-Cunha, F.; Salvini, T.F. Knee osteoarthritis induces atrophy and neuromuscular junction remodeling in the quadriceps and tibialis anterior muscles of rats. Sci. Rep. 2019, 9, 6366. [CrossRef] [PubMed]

33. Delfino, G.B.; Peviani, S.M.; Durigan, J.L.Q.; Russo, T.L.; Baptista, I.L.; Ferretti, M.; Moriscot, A.; Salvini, T.F. Quadriceps muscle atrophy after anterior cruciate ligament transection involves increased mRNA levels of atrogin-1, muscle ring finger 1, and myostatin. Am. J. Phys. Med. Rehabil. 2013, 92, 411-419. [CrossRef] [PubMed]

34. Sandri, M. Signaling in muscle atrophy and hypertrophy. Physiology 2008, 23, 160-170. [CrossRef] [PubMed]

35. Sakuma, K.; Yamaguchi, A. Sarcopenia and age-related endocrine function. Int. J. Endocrinol. 2012, 2012, 127362. [CrossRef]

36. Massague, J. TGF- $\beta$ signal transduction. Annu. Rev. Biochem. 1998, 67, 753-791. [CrossRef]

37. Elkina, Y.; von Haehling, S.; Anker, S.D.; Springer, J. The role of myostatin in muscle wasting: An overview. J. Cachexia Sarcopenia Muscle 2011, 2, 143-151. [CrossRef] 
38. Gigliotti, D.; Leiter, J.R.; Macek, B.; Davidson, M.J.; MacDonald, P.B.; Anderson, J.E. Atrophy, inducible satellite cell activation, and possible denervation of supraspinatus muscle in injured human rotator-cuff muscle. Am. J. Physiol. Cell Physiol. 2015, 309, C383-C391. [CrossRef]

39. Sajko, S.; Kubínová, L.; Cvetko, E.; Kreft, M.; Wernig, A.; Erzen, I. Frequency of M-cadherin-stained satellite cells declines in human muscles during aging. J. Histochem. Cytochem. 2004, 52, 179-185. [CrossRef]

40. Shefer, G.; Van de Mark, D.P.; Richardson, J.B.; Yablonka-Reuveni, Z. Satellite cell pool size does matter: Defining the myogenic potency of aging skeletal muscle. Dev. Biol. 2006, 294, 50-66. [CrossRef]

41. Anderson, J.E. The satellite cell as a companion in skeletal muscle plasticity: Currency, conveyance, clue, connector and colander. J. Exp. Biol. 2006, 209, 2276-2292. [CrossRef]

42. Tatsumi, R.; Hattori, A.; Ikeuchi, Y.; Anderson, J.E.; Allen, R.E. Release of hepatocyte growth factor from mechanically stretched skeletal muscle satellite cells and role of $\mathrm{pH}$ and nitric oxide. Mol. Biol. Cell 2002, 13, 2909-2918. [CrossRef] [PubMed]

43. Anderson, J.E.; Pilipowicz, O. Activation of muscle satellite cells in single fiber cultures. Nitric Oxide 2002, 7, 36-41. [CrossRef]

44. Tatsumi, R.; Anderson, J.E.; Nevoret, C.J.; Halevy, O.; Allen, R.E. HGF/SF is present in normal adult skeletal muscle and is capable of activating satellite cells. Dev. Biol. 1998, 194, 114-128. [CrossRef] [PubMed]

45. Ten Broek, R.W.; Grefte, S.; Von den Hoff, J.W. Regulatory factors and cell populations involved in skeletal muscle regeneration. J. Cell Physiol. 2010, 224, 7-16. [CrossRef] [PubMed]

46. Leiter, J.; Peeler, J.; Anderson, J. Exercise-induced muscle growth is muscle-specific and age-dependent. Muscle Nerve 2011, 43, 828-838. [CrossRef] [PubMed]

47. Szabo, C.; Ischiropoulos, H.; Radi, R. Peroxynitrite: Biochemistry, pathophysiology and development of therapeutics. Nat. Rev. Drug Discov. 2007, 6, 662-680. [CrossRef]

48. Powers, S.K.; Criswell, D.; Lawler, J.; Ji, L.L.; Martin, D.; Herb, R.A.; Dudley, G. Influence of exercise and fiber type on antioxidant enzyme activity in rat skeletal muscle. Am. J. Physiol. 1994, 266, R375-R380. [CrossRef]

49. McArdle, F.; Spiers, S.; Aldemir, H.; Vasilaki, A.; Beaver, A.; Iwanejko, L.; McArdle, A.; Jackson, M.J. Preconditioning of skeletal muscle against contraction-induced damage: The role of adaptations to oxidants in mice. J. Physiol. 2004, 561, 233-244. [CrossRef]

50. Powers, S.K.; Jackson, M.J. Exercise-induced oxidative stress: Cellular mechanisms and impact on muscle force production. Physiol. Rev. 2008, 88, 1243-1276. [CrossRef]

51. Barbieri, E.; Sestili, P. Reactive Oxygen Species in Skeletal Muscle Signaling. J. Signal. Transduct. 2012, 2012, 982794. [CrossRef]

52. Fulle, S.; Protasi, F.; Di Tano, G.; Pietrangelo, T.; Beltramin, A.; Boncompagni, S.; Vecchiet, L.; Fanò, G. The contribution of reactive oxygen species to sarcopenia and muscle ageing. Exp. Gerontol. 2004, 39, 17-24. [CrossRef] [PubMed]

53. Eigel, B.N.; Gursahani, H.; Hadley, R.W. ROS are required for rapid reactivation of $\mathrm{Na}^{+} / \mathrm{Ca}^{2+}$ exchanger in hypoxic reoxygenated guinea pig ventricular myocytes. Am. J. Physiol. Heart Circ. Physiol. 2004, 286, H955-H963. [CrossRef] [PubMed]

54. Bori, Z.; Zhao, Z.; Koltai, E.; Fatouros, I.G.; Jamurtas, A.Z.; Douroudos, I.I.; Terzis, G.; Chatzinikolaou, A.; Sovatzidis, A.; Draganidis, D.; et al. The effects of aging, physical training, and a single bout of exercise on mitochondrial protein expression in human skeletal muscle. Exp. Gerontol. 2012, 47, 417-424. [CrossRef] [PubMed]

55. Jackson, M.J.; Pye, D.; Palomero, J. The production of reactive oxygen and nitrogen species by skeletal muscle. J. Appl. Physiol. 2007, 102, 1664-1670. [CrossRef] [PubMed]

56. Espinosa, A.; Leiva, A.; Peña, M.; Müller, M.; Debandi, A.; Hidalgo, C.; Carrasco, M.A.; Jaimovich, E. Myotube depolarization generates reactive oxygen species through $\mathrm{NAD}(\mathrm{P}) \mathrm{H}$ oxidase; ROS-elicited $\mathrm{Ca}^{2+}$ stimulates ERK, CREB, early genes. J. Cell Physiol. 2006, 209, 379-388. [CrossRef] [PubMed]

57. Cherednichenko, G.; Zima, A.V.; Feng, W.; Schaefer, S.; Blatter, L.A.; Pessah, I.N. NADH oxidase activity of rat cardiac sarcoplasmic reticulum regulates calcium-induced calcium release. Circ. Res. 2004, 94, 478-486. [CrossRef]

58. Jackson, M.J. Redox regulation of muscle adaptations to contractile activity and aging. J. Appl. Physiol. 2015, 119, 163-171. [CrossRef]

59. DeLeo, F.R.; Quinn, M.T. Assembly of the phagocyte NADPH oxidase: Molecular interaction of oxidase proteins. J. Leukoc. Biol. 1996, 60, 677-691. [CrossRef] 
60. Carlson, C.L.; Visser, M.; Kelley, D.E.; Scherzinger, A.; Harris, T.B.; Stamm, E.; Newman, A.B. Attenuation of skeletal muscle and strength in the elderly: The Health ABC Study. J. Appl. Physiol. 2001, 90, 2157-2165. [CrossRef]

61. Kwon, Y.N.; Yoon, S.S. Sarcopenia: Neurological point of view. J. Bone Metab. 2017, 24, 83-89. [CrossRef]

62. Seidler, R.D.; Bernard, J.A.; Burutolu, T.B.; Fling, B.W.; Gordon, M.T.; Gwin, J.T.; Kwak, Y.; Lipps, D.B. Motor control and aging: Links to age-related brain structural, functional, and biochemical effects. NeuroSci. Biobehav. Rev. 2010, 34, 721-733. [CrossRef] [PubMed]

63. Tomlinson, B.E.; Irving, D. The numbers of limb motor neurons in the human lumbosacral cord throughout life. J. Neurol. Sci. 1997, 34, 213-219. [CrossRef]

64. Aagaard, P.; Suetta, C.; Caserotti, P.; Magnusson, S.P.; Kjaer, M. Role of the nervous system in sarcopenia and muscle atrophy with aging: Strength training as a countermeasure. Scand. J. Med. Sci. Sports 2010, 20, 49-64. [CrossRef] [PubMed]

65. Dorfman, L.J.; Bosley, T.M. Age-related changes in peripheral and central nerve conduction in man. Neurology 1979, 29, 38-44. [CrossRef] [PubMed]

66. Urbanchek, M.G.; Picken, E.B.; Kalliainen, L.K.; Kuzon, W.M., Jr. Specific force deficit in skeletal muscles of old rats is partially explained by the existence of denervated muscle fibers. J. Gerontol. A Biol. Sci. Med. Sci. 2001, 56, B191-B197. [CrossRef] [PubMed]

67. Navarro, A.; López-Cepero, J.M.; Sánchez del Pino, M.J. Skeletal muscle and aging. Front. BioSci. 2001, 6, D26-D44. [CrossRef]

68. Malisoux, L.; Francaux, M.; Theisen, D. What do single-fiber studies tell us about exercise training? Med. Sci. Sports Exerc. 2007, 39, 1051-1060. [CrossRef]

69. Mora, F.; Segovia, G.; del Arco, A. Aging, plasticity and environmental enrichment: Structural changes and neurotransmitter dynamics in several areas of the brain. Brain Res. Rev. 2007, 55, 78-88. [CrossRef]

70. Matthews, V.B.; Astrom, M.B.; Chan, M.H.; Bruce, C.R.; Krabbe, K.S.; Prelovsek, O.; Akerström, T.; Yfanti, C.; Broholm, C.; Mortensen, O.H.; et al. Brain-derived neurotrophic factor is produced by skeletal muscle cells in response to contraction and enhances fat oxidation via activation of AMP-activated protein kinase. Diabetologia 2009, 52, 1409-1418. [CrossRef]

71. Clow, C.; Jasmin, B.J. Brain-derived neurotrophic factor regulates satellite cell differentiation and skeletal muscle regeneration. Mol. Biol. Cell 2010, 21, 2182-2190. [CrossRef]

72. Marais, L.; Stein, D.J.; Daniels, W.M. Exercise increases BDNF levels in the striatum and decreases depressive-like behavior in chronically stressed rats. Metab. Brain Dis. 2009, 24, 587-597. [CrossRef] [PubMed]

73. Vilela, T.C.; Muller, A.P.; Damiani, A.P.; Macan, T.P.; da Silva, S.; Bortoluzzi-Canteiro, P.; Casagrande, A.S.; dos Santos-Pedroso, G.; Tiscoski-Nesi, R.; Moraes de Andrade, V.; et al. Strength and aerobic exercises improve spatial memory in aging rats through stimulating distinct neuroplasticity mechanisms. Mol. NeuroBiol. 2017, 54, 7928-7937. [CrossRef] [PubMed]

74. Aguiar, A.S., Jr.; Castro, A.A.; Moreira, E.L.; Glaser, V.; Santos, A.R.S.; Tasca, C.I.; Latini, A.; Prediger, R.D.S. Short bouts of mild-intensity physical exercise improve spatial learning and memory in aging rats: Involvement of hippocampal plasticity via AKT, CREB and BDNF signaling. Mech. Ageing Dev. 2007, 132, 560-567. [CrossRef] [PubMed]

75. Booth, F.W.; Ruegsegger, G.N.; Toedebusch, R.G.; Yan, Z. Endurance exercise and the regulation of skeletal muscle metabolism. Prog. Mol. Biol. Transl. Sci. 2015, 135, 129-151. [CrossRef]

76. Schaap, L.A.; Pluijm, S.M.; Deeg, D.J.; Harris, T.B.; Kritchevsky, S.B.; Newman, A.B.; Colbert, L.H.; Pahor, M.; Rubin, S.M.; Tylavsky, F.A.; et al. Higher inflammatory marker levels in older persons: Associations with 5-year change in muscle mass and muscle strength. J. Gerontol. A Biol. Sci. Med. Sci. 2009, 64, 1183-1189. [CrossRef]

77. Visser, M.; Pahor, M.; Taaffe, D.R.; Goodpaster, B.H.; Simonsick, E.M.; Newman, A.B.; Nevitt, M.; Harris, T.B. Relationship of interleukin- 6 and tumor necrosis factor- $\alpha$ with muscle mass and muscle strength in elderly men and women: The Health ABC Study. J. Gerontol. A Biol. Sci. Med. Sci. 2002, 57, M326-M332. [CrossRef]

78. Salminen, A.; Huuskonen, J.; Ojala, J.; Kauppinen, A.; Kaarniranta, K.; Suuronen, T. Activation of innate immunity system during aging: NF-kB signaling is the molecular culprit of inflamm-aging. Ageing Res. Rev. 2008, 7, 83-105. [CrossRef] 
79. Ferrucci, L.; Harris, T.B.; Guralnik, J.M.; Tracy, R.P.; Corti, M.C.; Cohen, H.J.; Penninx, B.; Pahor, M.; Wallace, R.; Havlik, R.J. Serum IL-6 level and the development of disability in older persons. J. Am. Geriatr. Soc. 1999, 47, 639-646. [CrossRef]

80. Di Marco, S.; Mazroui, R.; Dallaire, P.; Chittur, S.; Tenenbaum, S.A.; Radzioch, D.; Marette, A.; Gallouzi, I.-E. NF-kappa B-mediated MyoD decay during muscle wasting requires nitric oxide synthase mRNA stabilization, HuR protein, and nitric oxide release. Mol. Cell Biol. 2005, 25, 6533-6545. [CrossRef]

81. Hall, D.T.; Ma, J.F.; Marco, S.D.; Di Marco, S.; Gallouzi, I.-E. Inducible nitric oxide synthase (iNOS) in muscle wasting syndrome, sarcopenia, and cachexia. Aging 2011, 3, 702-715. [CrossRef]

82. Schaap, L.A.; Pluijm, S.M.; Deeg, D.J.; Visser, M. Inflammatory markers and loss of muscle mass (sarcopenia) and strength. Am. J. Med. 2006, 119, 526.e9-526.e17. [CrossRef] [PubMed]

83. Bencze, M.; Negroni, E.; Vallese, D.; Yacoub-Youssef, H.; Chaouch, S.; Wolff, A.; Aamiri, A.; Di Santo, J.P.; Chazaud, B.; Butler-Browne, G.; et al. Proinflammatory macrophages enhance the regenerative capacity of human myoblasts by modifying their kinetics of proliferation and differentiation. Mol. Ther. 2012, 20, 2168-2179. [CrossRef] [PubMed]

84. Bonato, M.; Turrini, F.; Galli, L.; Banfi, G.; Cinque, P. The role of physical activity for the management of sarcopenia in people living with HIV. Int. J. Environ. Res. Public Health 2020, 17, 1283. [CrossRef] [PubMed]

85. Hvid, L.; Aagaard, P.; Justesen, L.; Bayer, M.L.; Andersen, J.L.; Ortenblad, N.; Kjaer, M.; Suetta, C. Effects of aging on muscle mechanical function and muscle fiber morphology during short-term immobilization and subsequent retraining. J. Appl. Physiol. 2010, 109, 1628-1634. [CrossRef] [PubMed]

86. Suetta, C.; Hvid, L.G.; Justesen, L.; Christensen, U.; Neergaard, K.; Simonsen, L.; Ortenblad, N.; Magnusson, S.P.; Kjaer, M.; Aagaard, P. Effects of aging on human skeletal muscle after immobilization and retraining. J. Appl. Physiol. 2009, 107, 1172-1180. [CrossRef] [PubMed]

87. Glover, E.I.; Phillips, S.M. Resistance exercise and appropriate nutrition to counteract muscle wasting and promote muscle hypertrophy. Curr. Opin. Clin. Nutr. Metab. Care 2010, 13, 630-634. [CrossRef]

88. Wall, B.T.; Snijders, T.; Senden, J.M.; Ottenbros, C.L.P.; Gijsen, A.P.; Verdijk, L.B.; van Loon, L.J.C. Disuse impairs the muscle protein synthetic response to protein ingestion in healthy men. J. Clin. Endocrinol. Metab. 2013, 98, 4872-4881. [CrossRef]

89. Moncada, S.; Palmer, R.M.; Higgs, E.A. Nitric oxide: Physiology, pathophysiology, and pharmacology. Pharm. Rev. 1991, 43, 109-142.

90. Powers, S.K.; Radak, Z.; Ji, L.L. Exercise-induced oxidative stress: Past, present and future. J. Physiol. 2016, 594, 5081-5092. [CrossRef]

91. Gomes, M.J.; Martinez, P.F.; Pagan, L.U.; Damatto, R.L.; Cezar, M.D.M.; Lima, A.R.R.; Okoshi, K.; Okoshi, M.P. Skeletal muscle aging: Influence of oxidative stress and physical exercise. Oncotarget 2017, 8, 20428-20440. [CrossRef]

92. Marzani, B.; Felzani, G.; Bellomo, R.G.; Vecchiet, J.; Marzatico, F. Human muscle aging: ROS-mediated alterations in rectus abdominis and vastus lateralis muscles. Exp. Gerontol. 2005, 40, 959-965. [CrossRef] [PubMed]

93. Pansarasa, O.; Castagna, L.; Colombi, B.; Vecchiet, J.; Felzani, G.; Marzatico, F. Age and sex differences in human skeletal muscle: Role of reactive oxygen species. Free Radic. Res. 2000, 33, 287-293. [CrossRef] [PubMed]

94. Kim, J.S.; Cross, J.M.; Bamman, M.M. Impact of resistance loading on myostatin expression and cell cycle regulation in young and older men and women. Am. J. Physiol. Endocrinol. Metab. 2005, 288, E1110-E1119. [CrossRef] [PubMed]

95. Chen, M.; Cheng, C.; Yan, M.; Niu, S.; Gao, S.; Shi, S.; Liu, H.; Qin, Y.; Shen, A. Involvement of CAPON and nitric oxide synthases in rat muscle regeneration after peripheral nerve injury. J. Mol. NeuroSci. 2008, 34, 89-100. [CrossRef]

96. Petrella, J.K.; Kim, J.S.; Mayhew, D.L.; Cross, J.M.; Bamman, M.M. Potent myofiber hypertrophy during resistance training in humans is associated with satellite cell-mediated myonuclear addition: A cluster analysis. J. Appl. Physiol. 2008, 104, 1736-1742. [CrossRef]

97. Dreyer, H.C.; Blanco, C.E.; Sattler, F.R.; Schroeder, E.T.; Wiswell, R.A. Satellite cell numbers in young and older men 24 hours after eccentric exercise. Muscle Nerve 2006, 33, 242-253. [CrossRef] 
98. Verney, J.; Kadi, F.; Charifi, N.; Féasson, L.; Saafi, M.A.; Castells, J.; Piehl-Aulin, K.; Denis, C. Effects of combined lower body endurance and upper body resistance training on the satellite cell pool in elderly subjects. Muscle Nerve 2008, 38, 1147-1154. [CrossRef]

99. Kadi, F.; Schjerling, P.; Andersen, L.L.; Charifi, N.; Madsen, J.L.; Christensen, L.R.; Andersen, J.L. The effects of heavy resistance training and detraining on satellite cells in human skeletal muscles. J. Physiol. 2004, 558, 1005-1012. [CrossRef]

100. Lukaszyk, A.; Bodzenta-Lukaszyk, A.; Aksiucik, A.; Gabryelewicz, A.; Konturek, S.J.; Bielawiec, M. The role of epidermal growth factor in platelet-endothelium interactions. J. Physiol. Pharm. 1998, 49, 229-239.

101. Chakravarthy, M.V.; Spangenburg, E.E.; Booth, F.W. Culture in low levels of oxygen enhances in vitro proliferation potential of satellite cells from old skeletal muscles. Cell Mol. Life Sci. 2001, 58, 1150-1158. [CrossRef]

102. Ludlow, A.T.; Zimmerman, J.B.; Witkowski, S.; Hearn, J.W.; Hatfield, B.D.; Roth, S.M. Relationship between physical activity level, telomere length, and telomerase activity. Med. Sci. Sports Exerc. 2008, 40, 1764-1771. [CrossRef] [PubMed]

103. Kadi, F.; Ponsot, E.; Piehl-Aulin, K.; Mackey, A.; Kjaer, M.; Oskarsson, E.; Holm, L. The effects of regular strength training on telomere length in human skeletal muscle. Med. Sci. Sports Exerc. 2008, 40, 82-87. [CrossRef] [PubMed]

104. Beaudart, C.; Sanchez-Rodriguez, D.; Locquet, M.; Reginster, J.Y.; Lengelé, L.; Bruyère, O. Malnutrition as a strong predictor of the onset of sarcopenia. Nutrients 2019, 11, 2883. [CrossRef] [PubMed]

105. Paproski, J.J.; Finello, G.C.; Murillo, A.; Mandel, E. The importance of protein intake and strength exercises for older adults. JAAPA 2019, 32, 32-36. [CrossRef] [PubMed]

106. Abiri, B.; Vafa, M. The role of nutrition in attenuating age-related skeletal muscle atrophy. Adv. Exp. Med. Biol. 2020, 1260, 297-318. [CrossRef] [PubMed]

107. Buckley, C.M.; Austin, S.; Corfe, B.M.; Green, M.A.; Johnstone, A.M.; Stevenson, E.J.; Williams, E.A.; Brunstrom, J.M. Protein valuation in food choice is positively associated with lean mass in older adults. J. Nutr. 2019, 149, 2056-2064. [CrossRef]

108. Martínez-Arnau, F.M.; Fonfría-Vivas, R.; Buigues, C.; Castillo, Y.; Molina, P.; Hoogland, A.J.; van Doesburg, F.; Pruimboom, L.; Fernández-Garrido, J.; Cauli, O. Effects of leucine administration in sarcopenia: A ramdomized and placebo-controlled clinical trial. Nutrients 2020, 12, 932. [CrossRef]

109. Cruz-Jentoft, A.J.; Landi, F.; Schneider, S.M.; Zúñiga, C.; Arai, H.; Boirie, Y.; Chen, L.K.; Fielding, R.A.; Martin, F.C.; Michel, J.P.; et al. Prevalence of and interventions for sarcopenia in ageing adults: A systematic review. Report of the International Sarcopenia Initiative (EWGSOP and IWGS). Age Ageing 2014, 43, 748-759. [CrossRef]

110. Vitale, J.A.; Bonato, M.; La Torre, A.; Banfi, G. The role of the molecular clock in promoting skeletal muscle growth and protecting against sarcopenia. Int. J. Mol. Sci. 2019, 20, 4318. [CrossRef]

111. Eriksen, C.S.; Garde, E.; Reislev, N.L.; Wimmelmann, C.L.; Bieler, T.; Ziegler, A.K.; Gylling, A.T.; Dideriksen, K.J.; Siebner, H.R.; Mortensen, E.L.; et al. Physical activity as intervention for age-related loss of muscle mass and function: Protocol for a randomised controlled trial (the LISA study). BMJ Open 2016, 6, e012951. [CrossRef]

Publisher's Note: MDPI stays neutral with regard to jurisdictional claims in published maps and institutional affiliations.

(C) 2020 by the authors. Licensee MDPI, Basel, Switzerland. This article is an open access article distributed under the terms and conditions of the Creative Commons Attribution (CC BY) license (http://creativecommons.org/licenses/by/4.0/). 